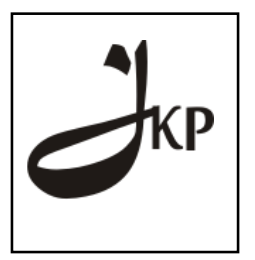

Jurnal Konseling dan Pendidikan

ISSN Cetak: 2337-6740 - ISSN Online: 2337-6880

DOI: https://doi.org/10.29210/117800

http://jurnal.konselingindonesia.com

Volume 5 Nomor 2. 2017. HIm 97-101

Info Artikel:

Diterima 24/04/2017

Direvisi 19/05/2017

Dipublikasikan 30/06/2017

\title{
Acceptance and Commitment Therapy (ACT) Bagi Penderita Gangguan Stress Pasca Bencana
}

\author{
Yessy Elita $^{1 *}$, Afifatus Sholihah ${ }^{2} \&$ Syahriman Sahiel ${ }^{3}$ \\ ${ }^{123}$ Universitas Bengkulu \\ $\risingdotseq$ e-mail: yessyelita@gmail.com ${ }^{*}$
}

\begin{abstract}
Abstrak
Bencana alam menjadi bagian yang tidak terpisahkan bagi masyarakat Indonesia mulai dari gempa bumi, tsunami, tanah longsor, banjir, dan bencana lainnya. Bencana ini menimbulkan dampak psikologis yang sangat besar berupa trauma dan stress pada individu, keluarga dan masyarakat. Gangguan stress pasca trauma (PTSD) merupakan reaksi maladaptif yang berkelanjutan terhadap suatu pengalaman traumatis yang dapat diderita berbulan-bulan bahkan bertahun-tahun. Kondisi demikian akan menurunkan kualitas hidup bagi penderitanya dalam jangka waktu yang lama. Oleh karena itu, salah satu penanganannya dengan menggunakan terapi ACT (acceptance and commitment therapy). Terapi ini merupakan terapi keperilakuan (behavioral) yang relatif baru dikembangkan dan digunakan untuk mengurangi perilaku menghindar atau melarikan diri dari pikiran-pikiran, emosi dan memori mengenai peristiwa-peristiwa yang traumatic. Perilaku menghindar ini kemudian digantikan dengan perilaku menerima peristiwa traumatis dan membuat komitmen untuk mengubah/ memperbaiki perilaku sesuai dengan tujuan-tujuan hidup klien. Tujuan akhr dari terapi ACT tidak hanya sekedar menghilangkan gejala-gejala trauma akan tetapi meningkatkan kualitas hidup klien di masa mendatang. Adapun tujuan artikel penelitian ini adalah untuk memberikan gambaran mengenai terapi ACT (Acceptance and Commitent Therapy), dan manfaatnya bagi penderita gangguan stress pasca bencana.
\end{abstract}

Kata Kunci: ACT, PTSD, stress, bencana

Copyright (C) 2017 IICET (Indonesia) - All Rights Reserved

Indonesian Institute for Counseling, Education and Therapy (IICET)

\section{PENDAHULUAN}

Kondisi geologis wilayah Indonesia merupakan pertemuan antara dua rangkaian jalur pegunungan muda yaitu sirkum pasifik dan sirkum mediteran dan juga kondisi geografis Indonesia yang berada pada posisi silang antara benua Asia dan Autralia serta dihampit dengan dua samudera yatu samudara Hindia dan pasifik sehingga menyebabkan Indonesia rawan terhadap berbagai jenis bencana alam (BNPB, 2010). Bencana alam yang sering dialami masyarakat Indonesia mulai dari gempa bumi, tsunami, tanah longsor, banjir, letusan gunung merapi, angin puting beliung dan bencana alam lainnya. Beberapa bencana alam yang paling memilukan terjadi antara lain: gempa dan tsunami di Aceh pada tanggal 26 desember 2004 yang memakan korban jiwa sebanyak 165.708 jiwa, 37.063 jiwa hilang dan kerugian materiil mencapai lebih 48 triliun. Begitu juga dengan gempa Padang yang terjadi pada tahun 2009 memakan korban jiwa 1.117 jiwa yang tewas, korban luka erat 1.214 jiwa dan kerugian materiil sampai triliunan rupiah.

Selain kerugian materiil, bencana alam ini secara umum mengakibatkan trauma dan stress pada individu, keluarga dan masyarakat (Ifdil, I., \& Taufik, T. 2012; Nirwana, H. (2016). Orang-orang mengalami kehilangan rumah, pekerjaan, komunitas dan harta benda. Bencana alam membawa dampak pada kesejahteraan emosional dan sosial bagi semua pihak baik orang dewasa, remaja dan anak-anak (Puteri, R. A. 2010). Anak-anak juga akan mengalami masalah kesehatan mental di masa datang akibat dari kejadian 
tersebut seperti kecemasan dan gangguan depresi (Sapienza \& Masten, 2011). Gangguan kecemasan dan stress yang dialami akibat bencana alam dikenal dengan gangguan stress pasca trauma (post traumatic stress disorder) (Nawangsih, E. 2016). PTSD adalah reaksi maladaptif yang berkelanjutan terhadap suatu pengalaman traumatis (Tentama, F. 2014). PTSD berlangsung berbulan-bulan, bertahun-tahun, atau sampai beberapa decade dan mungkin baru muncul setelah beberapa bulan atau tahun setelah adanya pemaparan terhadap peristiwa traumatis (Smith, Segal, \& Segal, 2008).

Smith, Segal dan Segal (2008) menjelaskan bahwa PTSD merupakan gangguan yang terbentuk dari peritiwa traumatik yang mengancam keselamatan dan membuat penderitanya tidak berdaya. PTSD sering dialami oleh tentara-tentara di medan perang, korban perkosaaan,korban kecelakaan, dan orang-orang yang kehilangan rumah, teman, lingkungan hidup akibat dari bencana alam atau musibah lainnya seperti kebakaran, dan kerusakan akibat terorisme. Gejala-gejala yang dialami oleh penderita PTSD ( meliputi: 1). merasakan kembali peritiwa traumatik dalam bentuk pikiran atau ingatan tidak menyenangkan tentang kejadian, mengalami mimpi buruk, dan mengalami perasaan menderita yang kuat saat mengingat kejadian traumatik, 2). menunjukkan gejala menghindar, terdiri atas usaha-usaha yang kuat untuk menghindari pikiran, perasaan atau pembicaraan mengenai kejadian traumatik, menghindari tempat-tempat yang mengingatkan akan trauma, kehilangan ketertarikan atas aktivitas-aktivitas positif, mengalami mati rasa emosional dan sulit untuk merasakan kesenangan atau kebahagiaan, dan 3) gejala Hyperarousal yang ditandai dengan kesulitan tidur, gelisah, sulit berkonsentrasi, mudah marah dan mengalami kebingungan (Koentara, 2014, online).

Gejala-gejala yang dialami oleh penderita PTSD dapat berlangsung dalam jangka waktu lama. Hal ini akan berdampak pada kesejahteraan subyektif dan kualitas hidup penderita di masa yang akan datang. Beberapa terapi dapat diberikan untuk mengatasi PTSD ini antara lain terapi perilaku, terapi cognitive behavioral (CBT), hipnoterapi, manajemen stress, dan lain sebagainya. Artikel ini membahas salah satu terapi yang sesuai untuk menangani gangguan stress pada penderita trauma akibat bencana alam, yaitu acceptance and commitment therapy (ACT). Terapi ini dapat dianggap belum sepopuler terapi cognitive behavioral, atau terapi keperilakuan lainnya. Hal ini dapat dilihat dari minimnya kajian pustaka berbahasa Indonesia yang membahas ACT dan penelitian-penelitian di Indonesia yang menggunakan terapi ACT.

\section{Acceptance and Commitment Therapy (ACT)}

ACT merupakan terapi behavioral yang dikembangkan oleh Hayes pada tahun 1986 (Hayes, 1996). ACT bertujuan untuk menciptakan hidup yang kaya makna dengan menerima segala rasa sakit yang mengikutinya. Berkurangnya gejala-gejala dianggap sebagai produk atau luaran sampingan dan bukan hal utama dibandingkan meningkatkan kualitas hidup klien. Terapi ini mengubah hubungan klien terhadap pikiran-pikiran dan perasaan rumit yang dialami selama ini dan diajarkan untuk mempersepsi pikiran dan perasaan tersebut sebagai sesuatu yang tidak mengancam.

Hayes (1996) berasumsi bahwa penderitaan psikologis yang dialami individu disebabkan oleh perilaku menghindar dan melarikan diri dari masalah yang dihadapi. Beberapa studi menunjukkan bahwa penghindaran dan perilaku lari dari masalah memainkan peran dalam memelihara gejala-gejala PTSD dan masalah-masalah trauma (Orsillo \& Batten, 2005). Bentuk-bentuk pelarian yang sering dilakukan individu antara lain: penggunaan obat-obatan, perilaku menyakiti diri sendiri, alkoholik, dan perilaku menghindar. Menekan pikiran ke alam bawah sadar seringkali tidak efektif dan secara paradox meningkatkan frekwensi pikiran-pikiran dan stress yang terkait dengannya.

Ada dua proses utama yang difokuskan dalam terapi ACT yaitu mengembangkan penerimaan pengalaman-pengalaman pribadi yang tidak diinginkan (acceptance) dan berkomitmen untuk melakukan tindakan yang sesuai dengan tujuan hidup klien (commitment). Klien yang datang dalam sesi terapi biasanya membawa agenda untuk mengendalikan emosi negatif. Mereka menginginkan untuk menghilangkan depresi, kecemasan-kecemasan, dan dorongan untuk minum alkohol, menghilangkan memori traumatik, perasaan harga diri yang rendah, ketakutan diabaikan, kemarahan, kesedihan, dan lain sebagainya. Klien-klien yang datang dalam sesi terapi seringkali telah menghabiskan banyak waktu, energi, dan uang untuk mengendalikan pikiran dan perasaan negatif yang dideritanya selama ini (Orsillo \& Batten, 2005).

Pada terapi ACT, seorang klien tidak diperbolehkan untuk mengurangi, mengubah, menghindari, menekan, atau mengontrol pengalaman-pengalaman pribadi yang traumatis. Klien belajar untuk berhenti berperang dengan pengalaman-pengalaman tersebut, memberikan ruang dan mengizinkan pengalaman- 
pengalaman tersebut untuk datang dan pergi dalam pikiran maupun perasaan tanpa ada usaha untuk menekan atau menghindari. Klien didorong untuk mengidentifikasi nilai-nilai atau tujuan hidup dan bertindak konsisten dengan nilai-nilai tersebut.

\section{Prinsip-Pinsip Inti dari Terapi ACT}

ACT menggunakan enam prinsip yang membantu klien untuk menangani masalah-masalah traumatis yang dialaminya antara lain: defusi kognitif, penerimaan, kontak dengan saat ini, mengamati diri sendiri, nilai-nilai hidup dan tindakan yang dijanjikan. Masing-masing prinsip memiliki metodologi spesifik, latihanlatihan, pekerjaan rumah dan metafora (Harris, 2006).

\section{Defusi}

Pikiran-pikiran kita seringkali tampak seperti kebenaran, aturan-aturan yang harus dipatuhi atau kejadian-kejadian penting yang memerlukan perhatian penuh atau ancaman-ancaman yang harus disingkirkan. Dengan kata lain, pikiran memiliki pengaruh terhadap perilaku manusia. Teknik defusi kognitif mengajarkan kepada klien untuk melangkah mundur dan mengamati bahasa tanpa terperangkap di dalamnya. Klien dapat mengenali bahwa pikiran-pikiran tersebut tidak lebih dari kejadian-kejadian pribadi yang sementara. Berbeda dengan cognitive behavior therapy, teknik defusi kognitif tidak mengevaluasi atau menentang pikiran-pikiran yang tidak diinginkan. Berikut ini adalah latihan sederhana dalam defusi kognitif:

1. Langkah pertama: bawa ke dalam pikiran bentuk-bentuk penghakiman diri negatif, misalnya:"Saya adalah....". Kalimat ini dapat diisi misalnya dengan "Saya tidak kompeten atau aku bodoh". Tahan pikiran tersebut beberapa detik dan yakinkanlah sebanyak kamu bisa. Sekarang bagaimana dampaknya buatmu?

2. Langkah kedua: sekarang dalam pikiran "Saya adalah..." lalu masukkan frasa "Saya mempunyai pikiran bahwa saya tidak kompetan" di depannya:. Sekarang pikirkan kembali dengan frasa baru tersebut. Apa yang dirasakan?.

Dalam tahap kedua, kebanyakan orang mengamati bahwa ada jarak dari pikiran, sehingga kalimat tersebut kurang memiliki dampak. Pada teknik ini tidak ada usaha untuk menyingkirkan dalam pikir ataupun mengubahnya, melainkan hubungan dengan pikiran telah berubah. Pikiran-pikiran tersebut dapat dipandang sekedar kata-kata.

\section{Acceptance}

Acceptance/penerimaan merupakan teknik kedua dalam terapi ACT. Teknik acceptance adalah membuat ruang untuk perasaan tidak senang, sensasi, dorongan-dorongan dan pengalaman-pengalaman pribadi lainnya, mengizinkan perasan-perasan tersebut untuk datang dan pergi tanpa melawan, berlari atau memberikan perhatian yang berlebihan. Sebagai contoh penggunaan teknik acceptance pada kasus Michael seorang yang mengalami gangguan kecemasan sosial dengan konselor ACT bernama Russel Harris.

Konselor Harris (Harris, 2006) membuat Michael merasakan kembali kecemasan dengan membayangkan berada di pesta kantor. Konselor meminta Michael untuk memindai tubuhnya dan mengamati di mana ia merasakan efek tidak nyaman dari cemas. Ia merasakan di daerah perut seperti ada simpul yang sangat besar. Michael diminta untuk mengamati sensasi dari rasa adanya simpul besar baik dari bentuk, getaran, berat, suhu, denyut dan sensasi-sensasi lainnya. Konselor mengajarkan Michael untuk memberikan "ruang" dan membiarkan sensasi yang tidak nyaman untuk tetap di sana meskipun ia tidak menyukai sensasi tersebut. Akhir dari terapi tersebut, Michael merasakan ketenangan dan merasa nyaman.

\section{Kontak dengan Kondisi Saat Ini}

Teknik ini mendorong untuk menyadari secara penuh di sini dan sekarang, penuh keterbukaan, minat, penerimaan dan terlibat penuh dengan apapun yang dikerjakan. Sebagai contoh Michael diberikan latihan mindfulness yang difokuskan dengan pengalaman makan. Michael diberikan makanan yang bernama sultana (makanan timur tengah) dan diminta untuk memakannya secara perlahan dengan memfokuskan pada rasa dan teksture buah dan suara kunyahan, sensasi, dan gerakan dalam mulut. Selama Michael melakukan mindfulness terhadap apa yang dimakannya, semua hal-hal yang mengganggu pikiran dan perasaan masih akan muncul. Ia diminta untuk membiarkan pikiran dan perasaan datang dan pergi dan ia diminta untuk tetap memfokuskan pada makanan tersebut.

\section{The Observing Self}

Klien diajarkan untuk mengamati secara langsung apa yang ada dalam pikiran, perasaan, memori, dorongan-dorongan, sensasi, citra diri, peran atau tubuh fisik. Fenomena ini mengubah secara konstan aspek- 
sapek dalam diri, tapi bukan esensi siapa diri klien. Pada latihan mindfulness, klien dia ajak untuk mengamati perbedaan antara pikiran yang muncul dan diri yang mengamati pikiran-pikiran tersebut. Dari perspektif the observing self, tidak ada pikiran berbahaya, mengancam atau mengontrol.

\section{Values (Nilai-nilai)}

Klien ditugaskan untuk mengklarifikasi hal-hal apa yang paling penting dan berarti dalam hidup, jenis orang seperti apa yang diinginkan oleh klien, dan hal apa yang ingin diperjuangkan dalam hidup. Pada kasus Michael, ia mengidentifikasi nilai-nilai yang penting adalah berhubungan dengan orang lain, mengembangkan intimasi, membangun persahabatan yang bermakna, dan menjadi otentik dan jujur. Konselor dan klien berdiskusi mengenai keinginan-keinginan yang akan diwujudkan.

\section{Committed Action (Tindakan yang Dijanjikan)}

Tindakan yang dijanjikan adalah bagian dari proses terapi ACT. Pada tahapan ini, klien membuat komitmen untuk mengambil tindakan yang sesuai dengan tujuan-tujuan hidupnya. Melanjutkan dengan sesi sebelumnya, Michael membuat tujuan yang selaras dengan nilai-nilainya. Pada awalnya, ia membuat tujuan untuk pergi makan siang dengan rekan kerjanya tiap hari, dan berbagi informasi pribadi dengan rekan kerjanya. Pada pertemuan berikutya, ia membuat tujuan sosial yang lebih menantang dan melanjutkan untuk berlatih mindfulness untuk mengatasi kecemasan dan perasaan yang tidak nyaman. Pada sesi akhir, Michael merasakan bahwa dia lebih lebih bersosialisasi dan yang terpenting adalah ia menyukai aktivitas-aktivitas yang dilakukannya. Pikiran-pikiran bahwa dia seorang pecundang, membosankan dan tidak akan disukai masih tetap ada, namun ia tidak memberikan perhatian dengan serius. Perasaan cemas masih terjadi dalam banyak situasi sosial, tapi tidak lagi mengganggu diri Michael.

\section{Penerapan ACT pada Penderita Gangguan Trauma Pasca Bencana}

Dengan melihat kondisi Indonesia yang rawan bencana, maka bencana alam adalah hal yang sulit dihindari, sulit diprediksi sehingga dapat datang kapan saja. Tidak sedikit penyitas gempa di Aceh, Padang dan Bengkulu yang berpindah tempat ke provinsi lainnya yang dianggap relatif aman dari gempa bumi. Begitu juga cukup banyak masyarakat yang tinggal di daerah pesisir meninggalkan rumahnya untuk menghindari dari potensi-potensi tsunami. Melarikan diri atau menghindari dengan berpindah tempat yang traumatis tidak akan menyelesaikan masalah. Penyintas bencana alam harus dapat menerima kondisi alam yang rawan bencana dan membiarkan pikiran dan perasaan yang negatif mengenai kejadian traumatik tanpa harus berusaha keras untuk menghilangkan gejala-gejala yang muncul akibat trauma. Penyintas bencana alam harus dapat mengalihkan fokusnya pada tujuan-tujuan hidup yang hendak dicapai agar kualitas hidup semakin membaik.

Banyak penderita/korban bencana alam yang kerugian materiil dan immaterial (kehilangan orang-orang dicintai, mengalami kecacatan, kehilangan pekerjaan dan lain-lain), akan berdampak penderitaan psikologis yang kronis. Kondisi ini tentunya dapat menurunkan kualitas hidupnya. Daripada memfokuskan pada kenangan-kenangan masa lalu dan ketidakberdayaan yang kronis, maka korban bencana alam dapat diajak untuk menyusun kembali rencana-rencana hidup yang tertunda dan melaksanakannya dengan penuh komitmen. Seiiring dengan bergantinya fokus kepada tujuan hidup yang ingin dicapai, maka lambat laun dampak lain seperti gejala-gejala yang muncul pasca trauma akan berkurang dengan sendirinya tanpa melakukan upaya keras untuk menghindari.

Penelitian-penelitian mengenai pengaruh atau efektivitas terhadap penyintas gangguan stress pasca bencana di Indonesia masih sangat terbatas dan bahkan literature dalam bahasa Indonesia juga sangat minim. Lebih lanjut, artikel ini dapat dijadikan bahan bagi mahasiswa bimbingan dan konseling, peneliti dan konselor untuk menggunakannya dalam penelitian lebih lanjut, sehingga dapat dibuktikan apakah terapi ACT efektif digunakan pada penderita/korban bencana alam.

\section{SIMPULAN DAN SARAN}

Terapi ACT adalah terapi behavioral yang relatif belum begitu popular dibandingkan dengan terapi kognitif dan keperilakuan lainnya. terapi ini dapat digunakan kepada penderita trauma, orang-orang yang mengalami kecemasan, harga diri rendah dan gangguan stress pasca trauma atau PTSD. Inti dari teknik ini adalah acceptance (penerimaan) dan komitmen. Perilaku menghindar atau lari dari pikiran-pikiran dan perasaan negatif akan memperburuk penderitaan psikologis seseorang. Dengan menerima gejala-gejala akibat 
dari kejadian-kejadian traumatik dan menyusun kembali tujuan-tujuan hidup akan meningkatkan kualitas hidup penderitanya dengan menggunakan enam teknik dalam terapi ACT yaitu defusi kogntif, penerimaan, kontak dengan situasi saat ini, mengamati diri, nilai-nilai dan berkomitmen untuk bertindak. Setiap teknik dapat dilakukan dengan metode mindfulness, memindai diri dan metafora yang dapat dikreasikan sendiri oleh konselor.

\section{DAFTAR RUJUKAN}

Harris, R. (2006). Embracing your demons: an overview of acceptance and commitment therapy. Pychotherapy in Australia, Vol. 12 (4): 1-8.

Hayes, S.C., Bisset, Roget,N., Padilla, M., Kohlenberg, B.S, Fisher, G., et al. (2004). The impact of acceptance and commitment training on stigmatizing attitudes and professional burnout of substance abuse counselors. Behavior therapy, Vol. 35, 821-836.

Hayes, S.C., Wilson, K.G., Gilford, E.V., Follete, V.M., \& Strosahl, K. (1996). Experiential avoidance and behavioral disorder: A functional dimensional approach to diagnosis and treatment. Journal of consulting and clinical psychology, 64, 1152-1168.

Ifdil, I., \& Taufik, T. (2012). Urgensi Peningkatan dan Pengembangan Resiliensi Siswa di Sumatera Barat. Pedagogi: Jurnal Ilmu Pendidikan, 12(2), 115-121.

Koentara, 2014. online http://www.dispsiad.mil.id/index.php/en/publikasi/artikel/221-post-traumatic-stressdisorder-ptsd.

Koentara,J.MenanganiKasusBencana.http://www.dispsiad.mil.id/index.php/en/publikasi/artikel/221-posttraumatic-stress-disorder-ptsd.

Nawangsih, E. (2016). Play Therapy Untuk anak-anak Korban Bencana Alam Yang Mengalami Trauma (Post Traumatic Stress Disorder/PTSD). Psympathic, 1(2), 164-178.

Nirwana, H. (2016). Konseling Trauma Pasca Bencana. Ta'dib, 15(2).

Orsillo, M.S., \& Batten, V.S. (2005). Acceptance and Commitment Therapy in the treatment of posttraumatic stress disorder. Behavior modification, Vol. 29 (1), 95-129.

Pratiwi, C. A., Karini, S. M., \& Agustin, R. W. (2012). Perbedaan Tingkat Post-Traumatic Stress Disorder Ditinjau Dari Bentuk Dukungan Emosi pada Penyintas Erupsi Merapi Usia Remaja dan Dewasa Di Sleman, Yogyakarta. Wacana, 4(8).

Puteri, R. A. (2010). Pendampingan Anak-anak Korban Lumpur Lapindo Kelurahan Jatirejo Kecamatan Porong Kabupaten Sidoarjo (Doctoral dissertation, UIN Sunan Ampel Surabaya).

Sapienza, J.K.\& Masten, A.S. (2011). Understanding and promoting resilience in children and youth. Current opinion in Psychiatry, 2(4), 267.

Smith, M., Segal, R., Segal, J. (2008). Posttraumatic stress disorder (PTSD): Symptoms, Treatment and SelfHelp.

Tentama, F. (2014). Peran Dukungan Sosial Pada Gangguan Stres Pascatrauma. Republika. 